\title{
PEMANFAATAN LIMBAH KELAPA SAWIT SEBAGAI PEWARNA ALAMI KAIN BATIK DENGAN FIKSASI
}

\section{(UTILIZATION OF PALM OIL WASTE AS NATURAL DYES BATIK CLOTH WITH FIXATION)}

\author{
Nurul Nofiyanti ${ }^{1 *}$, Ismi Eka Roviani ${ }^{2}$, Rina Dias Agustin ${ }^{3}$, \\ 1,2,3 JurusanTeknologi Hasil Pertanian, Fakultas Teknologi Pertanian, Universitas Jember \\ Jl. Kalimantan 37, Kampus Tegal Boto Jember 68121 \\ *e-mail: nofiantinurul@gmail.com
}

\begin{abstract}
ABSTRAK
Indonesia adalah salah satu penghasil kelapa sawit terbesar di dunia. Cangkang sebagai salah satu limbah dari pengolahan kelapa sawit dapat dimanfaatkan sebagai pewarna cokelat alami. Dalam proses pewarnaan kain batik, perlu dilakukan fiksasi untuk mempertahankan warna. Tujuan penelitian ini adalah untuk mengetahui karakteristik fisik dan organoleptik kain batik setelah dilakukan pewarnaan menggunakan pewarna alami cangkang kelapa sawit. Penelitian ini menggunakan dua faktor ( 2 kali ulangan). Faktor-faktor yang digunakan yaitu metode mordanting (pemanasan 1 jam dan pendiaman 24 jam) dan jenis fiksator (jeruk, kapur, dan tawas). Pembuatan pewarna alami dilakukan secara ekstraksi dengan pelarut air $\left(100{ }^{\circ} \mathrm{C}, 1\right.$ jam). Selanjutnya dilakukan proses fiksasi. Data dianalisa dengan menghitung rata-rata dan standar deviasi. Nilai lightness kain batik berkisar antara 71 sampai 88. Nilai hue angle berkisar antara 120 sampai 153. Sampel M1F2 (mordanting pendiaman 24 jam, fiksator kapur) adalah sampel yang paling disukai, sedangkan sampel M2F2 (mordanting 1 jam, fiksator kapur) adalah sampel yang tidak disukai. Sampel M2F2 memiliki lightness 88,3, hue angle 120,14 (yellow), dan tahan dari uji ketahanan gosok. Penggunaan metode mordanting dan jenis fiksator berpengaruh terhadap pewarnaan kain batik. Metode mordanting 24 jam dan fiksator kapur direkomendasikan dalam pewarnaan kain batik menggunakan pewana alami cangkang kelapa sawit berdasarkan uji kesukaan dan sifat fisik kain batik yang dihasilkan.

Kata kunci: Batik, Cangkang Kelapa Sawit, Pewarna Alami
\end{abstract}

\section{ABSTRACT}

Indonesia is one of the largest palm oil producers in the world. The shell as one of the waste of palm oil processing could be used as a natural brown dye. On the process of dyeing batik cloth, need to be done fixation to maintain the color. The aim of this study was to know the physical and organoleptic characteristic of batik cloth after dyeing process using natural dye of palm shell. The study design used two factors (2 repetitions). The factors used were mordanting method (1 hour heating and 24 hour shelter) and type of fixator (orange, lime, and alum). Natural dye processing was done by extraction using water as solvent $\left(100{ }^{\circ} \mathrm{C}, 1\right.$ hour). Furthermore, the process of fixation. Data were analyzed by calculating the average and standard deviation. The lightness value of batik cloth was about 71 to 88. The hue angle value was about 120 to 153. The M1F2 sample (mordanting 24 hour shelter, lime as fixator) was the most preferred sample, while the M2F2 sample (mordan 1 hour, lime fixator) was the 
disliked sample. The M2F2 sample had lightness of 88.3, hue angle of 120.14 (yellow), and had resistant to abrasion test. Method mordanting and type of fixator against batik dyeing cloth. Mordanting 24 hour and lime fixation fixtures in batik cloth dye using natural palm shell was recommended based on hedonic test and physical properties of batik cloth produced.

Keywords: Batik, Oil Palm Shell; Natural Dye

\section{PENDAHULUAN}

Batik merupakan kerajinan tangan hasil pewarnaan secara perintangan menggunakan malam (lilin batik) panas sebagai perintang warna dengan alat utama pelekat lilin batik berupa canting tulis atau canting cap untuk membentuk motif tertentu yang memiliki makna (Badan Standardisasi Nasional, 2014). Pembuatan batik dapat dilakukan melalui beberapa tahapan, diantaranya pembentukan motif, pewarnaan/pencelupan, fiksasi, dan pelorodan. Proses pewarnaan merupakan salah satu faktor yang dapat menentukan kualitas, daya tarik, dan arah warna batik. Dalam proses ini, dapat dilakukan menggunakan bahan pewarna alam karena pewarna sintetis memiliki kandungan kimia yang membahayakan kesehatan manusia dan secara tidak langsung mencemari lingkungan (Tocharman, 2009). Penggunaan warna alam pada batik menggunakan beberapa jenis tanaman pembawa warna, salah satunya adalah tanaman kelapa sawit.

Industri kelapa sawit merupakan salah satu industri strategis yang bergerak pada sektor pertanian yang banyak berkembang di negara-negara tropis seperti Indonesia, Malaysia, dan Thailand. Perkembangan industri kelapa sawit saat ini sangat pesat, dimana terjadi peningkatan jumlah produksi kelapa sawit seiring meningkatnya kebutuhan masyarakat. Limbah yang dihasilkan dari proses pengolahan minyak kelapa sawit adalah limbah padat, cair dan gas (Agustina, 2006). Limbah padat yang dihasilkan yaitu tandan kosong, cangkang, dan serat. Sedangkan limbah cair yang dihasilkan dari kegiatan industri pengolahan minyak kelapa sawit merupakan sisa dari proses pembuatan minyak kelapa sawit yang berbentuk cair (Pardamean, 2014). Apabila limbah ini diproses secara tepat akan memberikan manfaat yang cukup besar bagi industri dan dapat memberikan nilai tambah. Menurut Badan Pusat Statistik (2017), produksi cangkang kelapa sawit pada tahun 2015 adalah 2.033.479 ton dihitung dari 6,5\% produksi kelapa sawit sebanyak 31.284.300 ton. Limbah cangkang kelapa sawit jumlahnya cukup besar dan mempunyai potensi untuk dimanfaatkan sebagai boiler, makanan ternak, pengganti aspal dan pewarna alami pada kain batik karena adanya kandungan pigmen.

Pewarna merupakan salah satu bahan yang cukup luas penggunaannya dalam kehidupan sehari-hari, mislanya pada makanan, cat, tekstil, lukisan, kain dan lain sebagainya. Oleh karena itu, kebutuhan bahan pewarna diduga akan terus berkembang dan berkelanjutan. Penggunaan pewarna alami dapat menjadi alternatif untuk menggantikan pewarna sintetis dan juga untuk menggali sumber daya alam limbah perkebunan kelapa sawit yang belum dimanfaatkan serta mencoba bahan baku baru untuk pewarna batik. Hal ini mengingat penggunaan zat warna sintetis yang memiliki efek samping yang dapat merugikan kesehatan manusia seperti merangsang pertumbuhan kanker. Pewarna alami dapat diperoleh dari 
berbagai tumbuhan.Salah satunya tumbuhan yang dapat dijadikan pewarna alami kain batik adalah kelapa sawit.Bagian yang dapat digunakan sebagai pewarna alami yaitu cangkangnya. Cangkang kelapa sawit akan menghasilkan warna coklat yang alami. Hal ini dikarenakan cangkang kelapa sawit mengandung pigmen yang merupakan senyawa flavanoid sehingga memberikan warna coklat (Mussak dan Bechtold, 2009).

Menurut Paryanto dkk (2012), pigmen tanaman tidak permanen sehingga warna cepat memudar apabila terkena deterjen atau cahaya matahari. Agar zat warna alam mempunyai ketahanan luntur yang baik maka diperlukan proses fiksasi. Proses fiksasi adalah mengkondisikan zat pewarna yang telah terserap dalam bahan pada waktu tertentu agar terjadi reaksi yang kompleks antara bahan dengan zat pewarna dan bahan fiksator (Shofwan, 2015). Bahan fiksator berguna untuk meningkatkan daya serap kain terhadap zat warna alam, pada penelitian ini digunakan tawas, kapur tohor, dan ekstrak jeruk nipis.

Penggunaan pewarna alami kini mulai banyak diminati untuk berbagai industri pembatikan. Hal ini mengingat penggunaan zat warna alami dipandang lebih murah karena bahan baku banyak diperoleh di indonesia dan tidak memiliki efek samping yang membahayakan kesehatan manusia. Penelitian ini bertujuan untuk memanfaatkan limbah kelapa sawit sebagai sumber bahan baku baru zat warna alam dan sebagai alternatif pengganti pewarna sintetis. Zat warna alam yang diperoleh diharapkan dapat diaplikasikan dalam proses pewarnaan kain batik sutera.

\section{METODE}

Penelitian ini dilakukan di Laboratorium Rekayasa Teknologi Pangan dan Hasil Pertanian, Laboratorium Biokimia dan Laboratorium Enginering Hasil Pertanian Fakultas Teknologi Pertanian Universitas Jember. Waktu Penelitian dimulai pada April 2018 -Juni 2018.

Bahan yang digunakan yaitu $1 \mathrm{~kg}$ bubuk cangkang kelapa sawit, $90 \mathrm{~cm}$ kain katun, $5 \mathrm{~L}$ air, $74 \mathrm{~g} / \mathrm{L}$ tawas $\left(\mathrm{Al}_{2} \mathrm{SO}_{4}\right)_{3} . \mathrm{H}_{2} \mathrm{O}$, $50 \mathrm{~g} / \mathrm{L}$ kapur tohor $(\mathrm{CaOH})$, ekstrak jeruk nipis, deterjen dan soda api. Alat yang digunakan yaitu kompor, panci, spatula, kain saring, gelas ukur, baskom, ember, kamera, neraca analitik, colour reader, scanner dan pisau.

Penelitian ini merupakan penelitian eksperimental (experimental research) menggunakan Rancangan Acak Lengkap (RAL) dengan dua faktor yaitu beda perlakuan pada proses mordanting (M) dan perbedaan bahan fiksator (F). Macam dan kombinasi perlakuannya sebagai berikut :

$$
\begin{aligned}
& \text { Faktor M : Mordanting } \\
& \text { M1 : Perendaman } 24 \text { jam } \\
& \text { M2 : Pemanasan } 1 \text { jam } \\
& \text { Faktor F : Bahan fiksator } \\
& \text { F1 : Kapur tohor } \\
& \text { F2 : Jeruk } \\
& \text { F3 : Tawas }
\end{aligned}
$$

Rancangan diatas menggunakan model persamaan model sebagai berikut:

Tabel 1. Kombinasi Rancangan Percobaan

\begin{tabular}{ccc}
\hline Miksator $(\mathrm{F})$ & M1 & M2 \\
\hline F1 & F1M1 & F1M2 \\
F2 & F2M1 & F2M2 \\
F3 & F3M1 & F3M2 \\
\hline
\end{tabular}

Masing-masing kombinasi rancangan percobaan dilakukan sebanyak dua kali ulangan. Menurut Sugiyono 
(2012), Populasi merupakan wilayah generalisasi yang terdiri atas objek/subjek yang mempunyai kualitas dan karakteristik tertentu yang ditetapkan oleh peneliti untuk dipelajari dan kemudian ditarik kesimpulannya. Populasi dalam penelitian ini adalah Mahasiswa- Mahasiswi Universitas Jember yang aktif.

Penelitian dilakukan dengan 7 tahap yaitu pengambilan zat warna pada cangkang kelapa sawit dengan proses ekstraksi menggunakan $3 \mathrm{~L}$ air. Tahap kedua proses mordanting dengan dua perlakuan yaitu kain katun perendaman menggunakan larutan tawas yang sudah dipanaskan selama 24 jam (M1) dan pemanasan larutan tawas bersama kain selama 1 jam dengan suhu $\pm 80{ }^{\circ} \mathrm{C}(\mathrm{M} 2)$. Tahap ketiga pewarnaan kain katun hasil proses mordanting dengan zat warna yang didapat dengan cara pencelupan selama 5 menit sebanyak 10 kali. Tahap keempat pembuatan bahan fiksator dengan menggunakan 3 bahan fiksator yaitu $\mathrm{Al}_{2}\left(\mathrm{SO}_{4}\right)_{3} \cdot \mathrm{H}_{2} \mathrm{O}$ (tawas), $\mathrm{CaOH}$ (kapur tohor) dan ekstrak jeruk nipis. Tahap kelima fiksasi dengan mencelupkan sebanyak 10 kali kain berwarna pada larutan fiksator. Tahap keenam pelorodan lilin batik dengan air panas yang tercampur soda api. Tahap terakhir yaitu pengujan meliputi uji warna menggunakan colour reader, uji organoleptik dan uji ketahanan luntur terhadap gosokan dan pencucian.

\section{a. Ekstraksi}

Ekstraksi merupakan proses untuk mengambil zat warna dari cangkang kelapa sawit. Proses ekstraksi diawali dengan menimbang $1 \mathrm{~kg}$ bubuk cangkang kelapa sawit menggunakan neraca analitik, kemudian dilakukan ekstraksi selama 1 jam dengan menambahkan 3 L air hingga mendidih. Setelah proses ekstraksi, didapatkan ekstrak warna dari cangkang kelapa sawit. Ekstrak tersebut kemudian dilakukan penyaringan menggunakan kain saring untuk didapatkan zat pewarna halus yang terpisah dari ampas dan kotoran

b. Proses Mordanting

Proses mordanting berguna untuk menghasilkan kerataan dan ketajaman zat pewarna saat diaplikasikan pada kain serta menghasilkan warna yang permanen. Bahan yang digunakan yaitu 18 gram tawas yang dilarutkan pada masing-masing $1 \mathrm{~L}$ air sehingga tawas yang digunakan pada setiap perlakuan sebanyak 9 gram. Pada perlakuan pertama, larutan tawas dilakukan pemanasan selama 1 jam kemudian didinginkan dan dilakukan perendaman kain katun selama 24 jam (M1) untuk selanjutnya dikering anginkan. Pada perlakuan kedua, larutan tawas dilakukan pemanasan selama 1 jam dengan kain katun 30 $\mathrm{cm}$ yang dimasukkan pada proses pemanasan. Setelah dilakukan pemanasan selama 1 jam, dilakukan pendinginan (M2).

c. Proses Pewarnaan

Proses pewarnaan kain dilakukan dengan sistem pencelupan, yaitu kain katun hasil dari proses mordanting dilakukan pencelupan pada zat pewarna dari cangkang kelapa sawit selama 5 menit sebanyak 10 kali pengulangan dan pada setiap pencelupan dilakukan pengeringan menggunakan angin. Hal ini dilakukan untuk menghasilkan warna yang lebih tajam dan rata pada kain. Pada proses pewarnaan ini menghasilkan kain katun yang telah terwarnai dengan zat pewarna dari ekstrak cangkang kelapa sawit.

d. Pembuatan Bahan Fiksator

Bahan fiksator yang digunakan pada penelitian ini ada 3 jenis yaitu 50 gram tawas, 70 gram kapur tohor dan 
30 gram jeruk nipis. Fungsi dari bahan fiksator untuk mengunci zat warna alam pada kain agar tidak mudah luntur. Proses pembuatan bahan fiksator yaitu dengan mencampurkan masing-masing bahan fiksator dengan $1 \mathrm{~L}$ air. Setelah dicampur, dilakukan pendiaman selama 24 jam untuk mengendapkan cairan dan padatannya. Padatan tersebut yang dimaksud bahan fiksator dan digunakan pada proses selanjutnya.

e. Proses Fiksasi

Proses fiksasi bertujuan untuk mengkondisikan zat pewarna yang telah terserap pada kain pada waktu tertentu. Proses pertama yaitu 3 lembar kain katun yang telah terwarnai dilakukan pencelupan pada masing-masing bahan fiksator selama 15 menit. Setelah dicelupkan, kain diangkat dan dikeringkan menggunakan angin. Pengeringan menggunakan angin bertujuan untuk menjaga warna pada kain tidak mudah mudar dibandingkan dengan pengeringan menggunakan sinar matahari.

f. Proses Pelorodan

Proses pelorodan merupakan proses untuk melepaskan lilin batik pada kain katun yang terwarnai dengan cara memanaskan kain katun yang telah terwarnai dengan $1 \mathrm{~L}$ air dan 5 gram soda api selama 5-10 menit hingga lilin yang menempel pada kain kaun terlepas. Hasil dari proses pelorodan yaitu kain katun batik terwarna tanpa lilin.

\section{Proses Pengujian}

a. Uji Organoleptik

Uji organoleptik yang dilakukan meliputi warna, kenampakan dan keseluruhan. Cara pengujian dilakukan uji hedonik atau kesukaan. Pada penilaian uji kesukaan, panelis tidak terlatih berjumlah 26 orang diminta untuk memberikan kesan terhadap warna, kenampakan dan keseluruhan dari sampel pewarnaan kain batik dengan 6 kode sampel acak $(457 ; 281$; $973 ; 618 ; 594 ; 705)$ dan menggunakan skala sebagai berikut :

1 = sangat tidak suka; 2 = tidak suka

$3=$ agak suka; $4=$ suka; $5=$ sangat suka

b. Uji warna dengan color reader

Uji warna menggunakan alat color reader dengan cara menempelkan bagian pembaca warna pada kain yang akan diuji. Pengukuran warna dibaca pada parameter dL,da dan db pada 3 titik yang berbeda. Sebelum dilakukan pengukuran, color reader dikalibrasi terlebih dahulu menggunakan kain hitam untuk mengetahui nilai standar.

c. Uji ketahanan luntur terhdap gosokan dan pencucian

Uji ketahanan luntur terhadap gosokan dan pencucian menggunakan deterjen. Cara pengujian dilakukan dengan mencuci kain katun batik yang telah terwarna menggunakan detergen dan dilakukan gosokan sebanyak tiga kali gosokan serta penjumuran tersebut dilakukan sebanyak tiga kali ulangan.

\section{Analisis Data}

Data hasil pengamatan dianalisis secara deskriptif dan disajikan dalam bentuk tabel atau grafik.

\section{HASIL}

Industri batik belum ada yang membuat dan memanfaatkan pewarna alam dari limbah perkebunan yang berupa cangkang kelapa sawit sebagai bahan pewarna batik. Penelitian ini merupakan pemanfaatan sumber daya alam limbah perkebunan yang berupa cangkang kelapa 
sawit untuk pewarnaan pada batik dari bahan katun. Hasil uji kualitas pewarnaan yaitu meliputi uji organoleptik, uji ketahanan luntur terhadap gosokan dan pencucian serta pengujian kecerahan warna menggunkan color reader.

\section{Hasil Uji Organoleptik}

Hasil analisis organoleptik pewarnaaan kain batik dapat dilihat pada Grafik 1

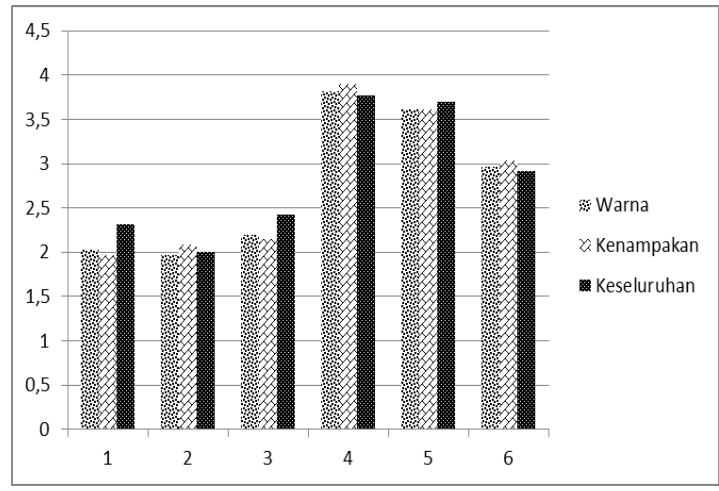

Gambar 1. Hasil Uji Organoleptik

Keterangan :

$457=$ mordanting pemanasan 1 jam,

fiksator kapur

$281=$ mordanting pemanasan $1 \mathrm{jam}$,

fiksator tawas

$973=$ mordanting pemanasan $1 \mathrm{jam}$,

fiksator jeruk

$618=$ mordanting 24 jam perendaman,

fiksator kapur

$594=$ mordanting 24 jam perendaman,

fiksator tawas

$705=$ mordanting 24 jam perendaman,

fiksator jeruk

a. Warna

Hasil penelitian menunjukkan bahwa perlakuan berbeda berpengaruh nyata terhadap tingkat kesukaan panelis. Rerata skor penilaian panelis terhadap warna kain batik hasil pewarna alami cangkang kelapa sawit dengan perlakuan mordanting pemansan 1 jam dan mordanting 24 jam perendaman dengan perbedaan bahan fiksator tawas, kapur dan jeruk dapat dilihat bahwa rerata warna panelis lebih suka dengan kode sampel 618 dengan nilai skor tertinggi $(3,81)$ hasil warna yang dihasilkan cenderung lebih gelap karena perlakuan mordanting perendaman 24 jam difiksasi kapur memiliki warna paling gelap yang diasumsikan warna yang paling baik. Hal ini sesuai dengan pernyataan Sulaeman (2000) bahwa adanya $\mathrm{Ca}^{2+}$ dari larutan kapur menyebabkan ikatan antara ion-ion dan tanin yang di dalam serat berikatan dengan serat lain, sehingga molekul zat warna tetap di dalam serat menjadi lebih kuat dan tidak mudah keluar. Berbeda dengan kode sampel 281 memiliki nilai terendah dengan skor $(1,96)$ karena warna yang dihasilkan terang mendekati warna putih sehingga rerata panelis tidak menyukainya. Hal ini menunjukkan

$457 \quad$ ah $281 \quad$ rl $\quad 973$ kc 618 np 594 yaitu musdanmı perenuaman $<4$ jam difiksasi kapur merupakan perlakuan terbaik untuk menghasilkan warna kain batik yang disukai panelis.

b. Kenampakan

Hasil penelitian menunjukkan pada setiap kode sampel memiliki tingkat kesukaan panelis yang berbeda. Rerata nilai kenampakan tertinggi pada sampel dengan kode 618 sebesar 3,9 sedangkan nilai kenampakan terendah pada sampel dengan kode 457 sebesar 1,96. Menurut Handayani dan Maulana (2013), kenampakan warna yang dihasilkan terjadi karena adanya reaksi dari senyawa flavanoid dengan logam $\mathrm{Al}^{3+}$ pada tawas dan $\mathrm{Ca}^{2+}$ pada kapur tohor sebagai bahan fiksator, sehingga memberikan arah warna yang berbeda pada proses mordan yang diaplikasikan pada kain katun. Artinya, setiap perbedaan 
perlakuan akan memberikan tingkat kecerahan warna yang berbeda pada kain hasil pewarna alami kelapa sawit. Maka dari itu dapat disimpulkan bahwa kenampakan suatu kain batik dapat dipengaruhi oleh proses mordanting dan bahan fiksator yang digunakan.

c. Keseluruhan

Hasil penelitian menunjukkan bahwa perlakuan pada setiap sampel dengan kode yang berbeda berpengaruh nyata terhadap tingkat kesukaan panelis. Rerata skor penilaian panelis terhadap tingkat keseluruhan kain hasil pewarna alami cangkang kelapa sawit dengan perbedaan proses mordanting dan fiksator yang berbeda dapat dilihat bahwa sampel dengan kode 618 lebih disukai panelis karena lebih halus dengan rerata nilai skor tertinggi 3,77 (menyukai) sedangkan pada sampel dengan kode 281 tingkat keseluruhan kain dengan rerata nilai skor terendah sebesar 2 dengan deskripsi kain yang tidak terlalu kasar, tidak kaku, cenderung lebih terang dan warna tidak merata. Hal ini didukung dengan pernyataan Suheryanto (2010), bahwa kapur memiliki warna putih atau putih keabu-abuan, dan kadang-kadang bernoda kekuningan atau kecokelatan yang disebabkan oleh adanya unsur besi. Sifat-sifat fisik kapur adalah berbentuk gumpalan yang tidak teratur, memiliki warna putih. Penggunaan larutan kapur sebagai fiksator merupakan penambahan garam-garam klorida atau oksalat dari basa-basa organik yang dapat meningkatkan afinitas zat warna terhadap selulosa/serat/kain katun. Artinya, penggunaan kapur sebagai fiksator dapat meningkatkan tingkat afinitas selulosa/serat/kain menjadi semakin baik.

\section{Hasil Uji Kualitas Warna Menggunakan Color Reader}

Pengukuran warna dilakukan dengan alat color reader. Prinsip dari color reader adalah pengukuran perbedaan warna melalui pantulan cahaya oleh permukaan sampel. Alat ini dapat membedakan warna kain batik berdasarkan Lightness (L) dan Hue (H). Nilai kecerahan dan Hue kain batik dari penelitian disajikan pada Tabel 1 .

Tabel 1. Hasil uji kualitas warna menggunakan color reader

\begin{tabular}{ccc}
\hline Sampel & $\mathbf{L}^{*}$ & $\mathbf{H u e}^{\circ}$ \\
\hline F1M1 & $80,54 \pm 6,03$ & $137,84 \pm 17,98$ \\
F1M2 & $74,11 \pm 3,25$ & $150,12 \pm 2,17$ \\
F2M1 & $85,31 \pm 4,24$ & $132,08 \pm 16,88$ \\
F2M2 & $83,21 \pm 1,41$ & $138,50 \pm 4,90$ \\
F3M1 & $81,26 \pm 3,01$ & $146,56 \pm 1,24$ \\
F3M2 & $78,14 \pm 3,35$ & $147,15 \pm 1,80$ \\
\hline
\end{tabular}

Hasil uji kualitas warna bila disajikan menggunakan grafik dapat dilihat pada Gambar 2.

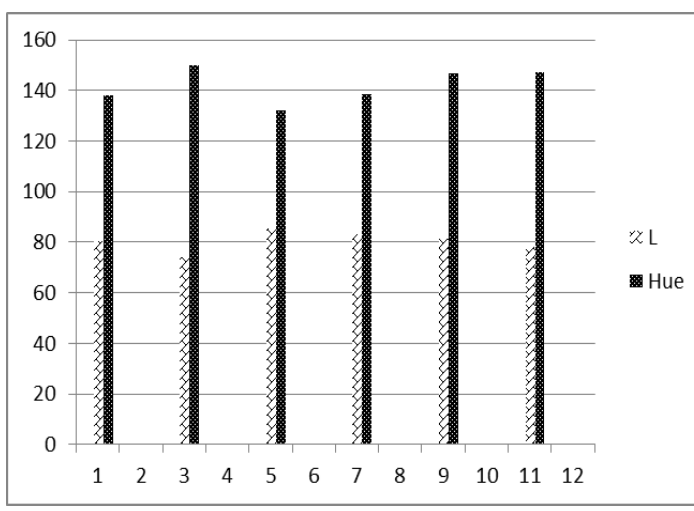

$\begin{array}{llllll}\text { F1 } & \text { F1 } & \text { F2 } & \text { F2 } & \text { F3 } & \text { F3 }\end{array}$

Gambar 2. Uji Kualitas Warna Menggunakan Color Reader 
Keterangan :

$\mathrm{F} 1 \mathrm{M} 1$ = mordanting perendaman $24 \mathrm{jam}$,

fiksator kapur

$\mathrm{F} 1 \mathrm{M} 2$ = mordantig pemanasan 1 jam,

fiksator kapur

F2M1 = mordanting perendaman 24 jam,

fiksator jeruk

$\mathrm{F} 2 \mathrm{M} 2$ = mordanting pemanasan $1 \mathrm{jam}$,

fiksator jeruk

F3M1 = mordanting perendaman $24 \mathrm{jam}$,

fiksator tawas

$\mathrm{F} 3 \mathrm{M} 2=$ mordanting pemanasan $1 \mathrm{jam}$,

fiksator tawas

Nilai lightness merupakan tingkatan warna berdasarkan pencampuran dengan unsur warna putih sebagai unsur warna yang memunculkan kesan terang atau gelap. Nilai korelasi warna lightness berkisar antara 0 untuk warna paling gelap (hitam) dan 100 untuk warna paling terang (putih). Dari grafik tersebut tampak bahwa sampel kain batik F2M1 memiliki nilai L lebih tinggi (paling cerah) dari perlakuan mordanting dengan perendaman 24 jam, fiksator jeruk yaitu sebesar 85,31 44,24 dibandingkan dengan sebesar F1M2 dari perlakuan mordanting dengan pemanasan 1 jam, fiksator kapur yaitu sebesar $74,11 \pm 3,25$ (paling gelap). Hal ini disebabkan oleh adanya perbedaan lama perlakuan mordanting dan perbedaan bahan fiksator. Perbedaan pada saat proses mordanting mempengaruhi kecerahan warna yang dihasilkan, begitu juga dengan perbedaan bahan fiksator yang digunakan. Proses mordantig yang baik akan menghasilkan warna yang permanen dan menghasilkan kerataan serta ketajaman warna yang baik (Roetjito, 1979). Perlakuan dengan mordanting pemanasan 1 jam (F1M2) lebih menghasilkan warna lebih gelap dibandingkan perlakuan mordanting perendaman 24 jam (F2M1). Hal ini dikarenakan pada saat proses mordanting pemanasan 1 jam pori-pori kain katun terbuka sehingga meningkatkan daya tarik zat warna alam dan menghasilkan kerataan dan ketajaman warna yang baik pada kain batik. Bahan fiksator menggunakan tawas cenderug menghasilkn warna kearah gelap sedangkan bahan fiksator cenderung menghasilkan warna kearah terang.

Nilai hue adalah karakteristik warna berdasarkan cahaya yang dipantulkan oleh objek yang merupakan nilai keseluruhan yang didominasi pada suatu produk atau warna utama produk. Hasil pengukuran nilai hue kain batik menunjukkan bahwa nilai hue tertinggi terdapat pada sampel F1M2 sebesar $150,12 \pm 2,17$, sedangkan nilai hue terendah terdapat pada sampel F2M1 sebesar $132,08 \pm 16,88$. Nilai hue yang didapatkan kemudian dimasukkan pada rumus konversi sehingga dapat dideskripsikan warnanya berdasarkan Tabel 2.

Tabel 2. Deskripsi warna berdasarkan hue angle

\begin{tabular}{cc}
\hline $\begin{array}{c}{ }^{\circ} \text { Hue [arc } \\
\text { tan }(\mathbf{b} / \mathbf{a})]\end{array}$ & Deskripsi warna \\
\hline $18-54$ & Red $($ R) \\
$54-90$ & Yellow Red $(\mathrm{YR})$ \\
$90-126$ & Yellow $(\mathrm{Y})$ \\
$126-162$ & Yellow Green $(\mathrm{YG})$ \\
$162-198$ & Green $(\mathrm{G})$ \\
$198-234$ & Blue Green $(\mathrm{BG})$ \\
$234-270$ & Blue $(\mathrm{B})$ \\
$270-306$ & Blue Purple $(\mathrm{BP})$ \\
$306-342$ & Purple $(\mathrm{P})$ \\
$342-18$ & Red Purple $(\mathrm{RP})$ \\
\hline
\end{tabular}

Berdasarkan hasil analisis dari semua sampel menunjukkan bahwa nilai hue yang diperoleh dideskripsikan yellow green (YG). Salah satu faktor yang mempengaruhi oleh kandungan flavanoid dan karbon pada cangkang kelapa sawit yang memberikan warna cokelat. Proses 
fiksasi dengan kapur, tawas dan jeruk nipis akan memberikan warna kuning kehijauan karena pengaruh kandungan kimia yang terdapat dalam bahan fiksasi, yakni $\mathrm{Ca}^{2+}$ dan $\mathrm{Al}^{3+}$ pada kapur dan tawas yang memberikan warna kearah lebih gelap sedangkan difiksasi dengan ekstrak jeruk nipis akan memberikan warna kearah lebih cerah

\section{Hasil uji ketahanan luntur terhadap gosokan dan pencucian}

Berdaskan hasil pengamatan perubahan warna dari hasil ekstraksi cangkang kelapa sawit dengan pengujian tahan luntur terhadap gosokan dan pencucian dapat dilihat pada tabel berikut:

Tabel 3. Hasil uji ketahanan luntur terhadap gosokan da pencucian

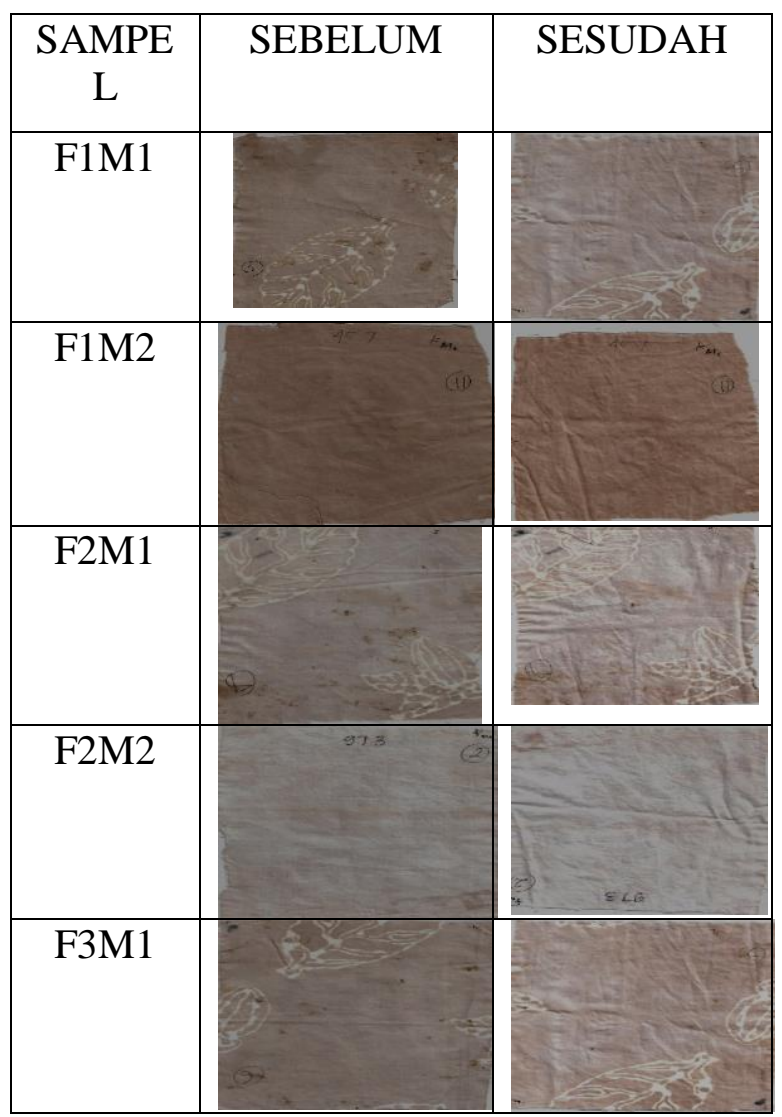

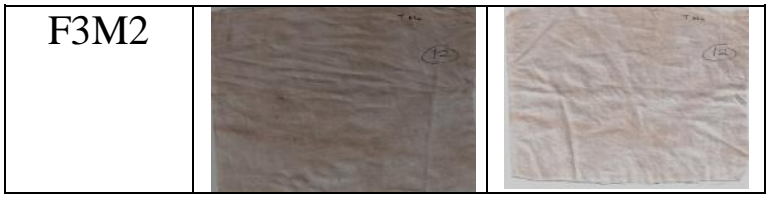

Berdasarkan hasil pewarnaan secara visual diperoleh warna kecoklatan, seperti pada Tabel 3. Arah warna yang didapatkan disebabkan oleh kandungan zat cangang kelapa sawit sehingga memberikan warna coklat kekuningan. Sampel F1M2 hasil hasil mordanting pemanasan 1 jam yang difiksasi dengan kapur memiliki perbedaan yang tidak terlalu terlihat pada saat sebelum dan sesudah dilakukan penggosokan dan pencucian dibandingkan dengan sampel F3M2 dari hasil mordanting perendaman 24 jam difiksasi tawas. Hal ini diduga adanya interaksi dari hasil ekstraksi cangkang kelapa sawit dapat meresap baik ke dalam serat kain dan diikat baik dengan bahan fiksasi sehingga pada saat melakukan pengujian terhadap gosokan dan pencucian deterjen, zat warna yang terdapat pada kain tidak mudah lepas.

\section{KESIMPULAN}

Hasil uji organoleptik yang paling banyak disukai panelis yaitu sampel dengan kode 618 dengan perlakuan mordanting perendaman 24 jam (M1) menggunakan bahan fiksator kapur tohor (F1).

Hasil uji warna menggunakan color reader menunjukkan hasil $\mathrm{L}$ (lightness) tertinggi diperoleh pada F2M1 yaitu dengan perlakuan mordanting perendaman 24 jam dan bahan fiksator jeruk nipis, namun dari semua sampel menunjukkan hasil yang tidak jauh yaitu berkisar 74-85 yang menunjukkan hasil yang mendekati warna terang (putih). Nilai Hue dari semua sampel menunjukkan nilai berkisar 132-150 yang menandakan warna Yellow Green (YG). 
Hasil uji ketahanan luntur terhadap gosokan dan pencucian menggunakan deterjen menunjukkan hasil dari semua sampel memiliki hasil yang tidak jauh berbeda perubahan warnanya namun ada satu sampel yang sangat terlihat perubahannya yaitu sampel F3M2 dan yang tidak terlalu terlihat perubahannya sampel F1M2

\section{SARAN}

Perlu adanya penelitian lebih lanjut mengenai metode pembuatan pewarna alami kain batik menggunakan cangkang kelapa sawit yang menghasilkan warna tajam dan rata pada pewarnaan kain batik, mengingat banyaknya limbah kelapa sawit yang melimpah dan tidak banyak dimanfaatkan.

\section{KEPUSTAKAAN}

Akhmad Sofwan. (2015). "Belajar PHP dengan Framework CodeIgniter", [online] Available : http://mcd.bis.telkomuniversity.ac.i d/file/CodeIgniter/belajar-phpdengan-framework-code-igniter.pdf Agustina, H. 2006. Land Apllication Sebagai Alternatif 3R Pada Industri Kelapa Sawit. Kementrian Negara Lingkungan Hidup. Pengelolaan Bahan dan Limbah Berbahaya dan Beracun. http://menlh.go.id. [diakses pada 06 Juni 2018].

Bechtold T, Rita Mussak. 2009.

"Handbook of Natural Coloranst". Leopold-Franzens University : Austria

BPS, Biro Pusat Statistik. (2015). Nilai Produksi dan Biaya Produksi per Hektar Usaha Perkebunan Kelapa Sawit dan Tebu. http://www.bps.go.id/linkTabelStat is/view/id/1853. Jakarta: BPS
[BSN] Badan Standarisasi Nasional., 2014 SNI 7182:2015, "Kelapa sawit", Badan Standar Nasional.

Handayani, P.A., dan Maulana, I. (2013). Pewarna alami batik dari kulit soga tingi (Ceriops tagal) dengan metode ekstraksi. Jurnal Bahan Alam Terbarukan. 2(2): 1-6.

Hutching, J.B. 1999. Food Color and Apearance.Aspen publisher Inc., Maryland.

Roetjito, dkk. Teori Pengujian Tekstil 1, DMPK Jakarta, Depdikbud, 1979.

Pardamean, Maruli., (2014), Mengelola Kebun dan Pabrik Kelapa Sawit Secara Profesional, Jakarta: Penebar Swadaya

Paryanto, Purwanto, A., Kwartiningsih, E., dan Mastuti, E.

2012.Pembuatan Zat warna Alami dalam Bentuk Serbuk untuk Mendukung Industri Batik di Indonesia. Jurnal Rekayasa Proses, 6(1): 26-29

Suheryanto, D dan Haryanto, G. (2008).

Pengaruh konsentrasi tawas terhadap ketuaan dan ketahanan luntur warna pada pencelupan kain sutera dengan zat warna gambir. Dinamika Kerajian dan Batik. (25): 9-16.

Sugiyono. 2012. Metode Penelitian

Kuantitatif Kualitatif dan R\&D.

Bandung: Alfabeta.

Sulaeman. (2000). Peningkatan

Ketahanan Luntur Warna Alam

Dengan Cara Pengerjaan Iring.

Yogyakarta: Balai Besar

Kerajianan Dan Batik.

Tocharman, M. 2009. Seri Pembelajaran.

Diklat/BIMTEK KTSP DIT.

Pembinaan SMA : DEP-DIKNAS 